\title{
Oral Hemorrhage
}

National Cancer Institute

\section{Source}

National Cancer Institute. Oral Hemorrhage. NCI Thesaurus. Code C79699.

Bleeding originating from the mouth. 